Close collaboration with the Central Planning Authority (JUCE-PLAN) and with other bodies was necessary to achieve proper integration of science and technological plans with the socioeconomic and cultural development of the country and to ensure that the science and technology plan would be one of the categories of the national economic plan. The 1976-80 economic plan was approved at the first Congress of the Cuban Communist Party in December 1975, and has three aims: to increase and diversify agricultural production to make the country self sufficient in food; to increase industrialisation; and to increase the production of sugar and nickel to pay for imports.

In agriculture the main areas of expansion will be rice, vegetables, citrus, poultry, fisheries and livestock. Industrial production will be increased in all areas, particularly fertilisers, steel, cement, paper and agricultural machinery. It is planned to produce about 600 cane harvesters a year from a Cuban design; this will reduce the workforce in the sector from about 370,000 to 50,000 by 1980 . A nuclear reactor with capacity $880 \mathrm{MW}$ will be built with Soviet assistance; in 1975 Cuban electrical generating capacity was $6.5 \times 10^{12} \mathrm{~W}$ (about $700 \mathrm{kWh}$ per inhabitant) but this is expected to increase by $35 \%$ over the next five years.

In 1959 sugar constituted $80 \%$ of Cuban exports and it held a similar position in 1970. In the future it is expected that the extensive Cuban nickel deposits will take over the role of main exchange earner, hence the $300 \%$ proposed expansion in nickel production.

\section{CNCT plan}

The CNCT drew up a plan for 197680 to link up with the national economic plan, slowly integrating indigenous research with technology transfer. Technology transfer is considered by Cubans to be indispensable to rapid economic development, but for it to be effective it must be adapted to local conditions and that means a large research and development base is essential. The CNCT plan focuses on the exploitation of Cuba's extensive laterite deposits; the application of nuclear technology and solar energy; the development of the electronics industry (to produce 100,000 television sets and 300,000 radios per year) and the development of computing and information systems (Cuban designed mini-computers are now being manufactured with Japanese componentsunder a Soviet-Cuban agreement, Cuba will provide the Comecon countries with certain components); the use of local products; and agriculture,

\section{Cuban chronicle}

Over the past hundred years Cuba has undergone three major transformations, and the development of its science and technology policy has tended to reflect this historical development.

The second half of the nineteenth century, ending with the first US intervention from 1898-1902, coincided with the rise of Cuban national consciousness and the struggle against Spanish colonialism. The first Cuban Academy of Sciences was founded in 1860 , immediately prior to the Ten Years War, by about thirty European-trained academics, many of whom made contributions to world science. Attempts to introduce scientific and technical methods to Cuban agriculture, then in a primitive state, were unsuccessful; colonial conditions meant the Academy was 'peripheralised', and new development stemmed from technology transfers rather than indigenous sciences. By 1895 there were 1,186 students in institutions of secondary education- -0.7 per thousand of population; the subjects studied were mainly Greek, Latin and rhetoric.

Cubans view the period beginning in 1902 and ending in 1958 as "the period of the neo-colonial republic marked by the presence of American imperialism." Local scientific activity was minimal and there were few research centres. The Academy of Sciences suffered a slow decline: by 1959 its yearly state budget was $\$ 600$ and it did not possess a librarian. It was attached to the Ministry of Justice, while the Geographical Society of Cuba fell under the Ministry of State and the National Observatory was part of the Ministry of Sea and War. By 1958 15,000 students were enrolled in higher education, with $11 \%$ studying science and technology. About 60,000 students were in secondary education, representing about 10 per thousand of population. American missions in 1937 and 1950 commented on the paucity of technicians, the scientific and technological backwardness of the country and especially in the sugar industry, and the lack of facilities for research at the University of Havana.

The period was one of great political instability and culminated in the Batista dictatorship. The plantation economy, dependent on sugar for more than $80 \%$ of exports, was heavily reliant upon the US economy both in terms of trade and direct investment. The urban/rural dualism intensified, and by 1958 Cuba had half a million unemployed and two million illiterates and semi-literates in a population of 6.5 million. The period is seen as one of increasing cultural domination with continual attempts to belittle Cuban achievements. The example is cited of the recognition given to the American Dr Walter Reed as the discoverer of the carrier of yellow fever; in Cuba the Cuban Academician Dr Carlos Finlay is considered to have deciphered the problem.

The successful revolution of Fidel Castro and his followers in 1959 marked the start of Cuba's third period. Influenced by Soviet industrialisation, Castro and particularly Ché Guevara felt that a similar programme was necessary for the Cuban revolution to succeed. Science and technology were therefore recognised as critical factors in social and economic development, and in spite of a critical resource shortage, human and material resources were allocated for the creation of research centres to meet the requirements of the development plan.

The development plan which emerged for 1961-63 followed eighteen months characterised no less by chaos and government measures to gain control over all aspects of Cuban society, than by a programme of agrarian reform and a campaign to eradicate illiteracy. It was drawn up by Guevara and was intended to transform the Cuban economy from an agricultural to an industrial structure. It was expected to accelerate development on many fronts by means of import substitutions with emphasis on heavy industry. The programme exceeded Cuba's technical, administrative and resource capabilities; it ended as a failure.

The second growth strategy from 1964-75 reoriented previous. plais, with their emphasis on agriculture, to centre on sugar and exports. Industrialisation remained the long term objective, but it was to be a gradual process with immediate expansion on a few fronts, such as cement manufacture, fertilisers and steel. Consequently, the science and technology infrastructure continued to expand, particularly in the training of personnel and in the establishment of research centres (see main story). 